Jurnal Artikel

\title{
Pengaruh Electroplating Krom Terhadap Ketebalan Dan Kekerasan Lapisan Pada Jari-Jari Sepeda Motor Yang Telah Di-Electroplating Nikel
}

\author{
Fauzan Fikrat Winata ${ }^{1)}$, Agus Fikri ${ }^{\left.1^{*}\right)}$, M Mujirudin ${ }^{2)}$ \\ ${ }^{1}$ Program Studi Teknik Mesin, Fakultas Teknik Universitas Muhammadiyah Prof. DR. Hamka \\ ${ }^{2}$ Program Studi Teknik Elektro, Fakultas Universitas Muhammadiyah Prof. DR. Hamka \\ Universitas Muhammadiyah Prof DR.HAMKA \\ JL. Tanah Merdeka No 6, Kp. Rambutan, Pasar Rebo Jakarta Timur- Indonesia \\ Telp: (021)87782739, Fax 021-840091, Mobile +6288213395645 \\ Email: agus_fikri@uhamka.ac.id
}

Artkel Info -: Received: 3 Dec 2021; Revised: 7 Jan 2022; Accepted: 10 Jan 2022

\begin{abstract}
Tujuan dari penelitian ini adalah untuk mengetahui pengaruh hasil electroplating krom terhadap ketebalan dan kekerasan pada jarijari sepeda motor yang telah di-electroplating nikel. Penelitian ini dilakukan ruang laboratorium PT.Enkei Indonesia dan PT. Murni Cahaya Pratama bekasi, Jawa barat, Indonesia antara Januari - Maret 2021 dengan menggunakan pelapisan electroplating krom, jari-jari sepeda motor terbuat dari material baja st37 yang sudah dilakukan pelapisan electroplating nikel, kemudian electroplating krom. Parameter penelitian adalah kuat arus pencelupan 4A, 6A, dan 8A. Pengujian yang dilakukan adalah ketebalan, kekerasan, struktur makro dan struktur mikro. Hasil penelitian menunjukkan bahwa pengaruh kuat arus terhadap pelapisan electroplating menghasilkan nilai tertinggi ketebalan dengan rata-rata $26,77 \mu \mathrm{m}$, struktur mikro bersifat tahan korosi dan non magnetic, struktur makro menunjukkan hasil bercak hitam berindikasi cacat seperti porositi dan nilai tertinggi kekerasan dengan rata- rata $4 \mathrm{H}$.

Kata kunci: electroplating, ketebalan dan kekerasan, pelapisan nikel-krom
\end{abstract}

\begin{abstract}
The purpose of this study was to determine the effect of chrome electroplating on the thickness and hardness of the spokes of a motorcycle wich has been electroplating nikel. This research was conducted in the laboratory room of PT. Enkei Indonesia and PT. Murni Cahaya Pratama Bekasi, West Java, Indonesia between January - March 2021 using nickel-chrome electroplating, the spokes of the motorcycle are made of st 37 steel which has been electroplated with nickel, then electroplated with chrome. The parameters of the research were 4A, 6A, and $8 A$ immersion currents. The tests carried out are thickness, hardness, macro structure and micro structure. The results showed that the effect of the strong current on the electroplating coating resulted in the highest value of thickness with an average of $26.77 \mu \mathrm{m}$, the microstructure was corrosion resistant and non-magnetic, the macro structure showed the results of black spots indicating defects such as porosity and the highest value of hardness with an average $4 H$

Keywords: electroplating, thicness and hardness, nickel-chrome coating
\end{abstract}

(c) 2020 by authors. Lisensi Jurnal Metal : Manufaktur, Energi, Material Teknik, Uhamka, Jakarta. Artikel ini bersifat open access yang didistribusikan di bawah syarat dan ketentuan Creative Commons Attribution (CC-BY) license.

\section{PENDAHULUAN}

Baja karbon rendah merupakan salah satu jenis logam yang dapat digunakan pada dunia industri. Jenis logam ini mempunyai batas tertentu dalam hal menjaga ketahanan korosi(Apriambudi, 2019). Oleh karena itu diperlukan upaya lebih untuk memperbaiki performa kerja dari setiap baja karbon rendah agar mendapatkan hasil ketahanan korosi lebih baik lagi, maka dapat dilakukan untuk meningkatkan kemampuan lebih. Salah satu cara untuk meningkatkan ketahanan korosi salah satunya adalah meningkatkan ketahanan korosi dari baja karbon rendah dengan memberikan lapisan proteksi pada permukaan baja karbon rendah dengan paduan yang memiliki ketahanan tinggi terhadap lingkungan korosif (Rasyad \& Arto, 2018).

Metode electroplating yaitu satu salah satu cara yang dapat memperindah permukaan dengan memberi lapisan proteksi yang akan meningkatkan kekerasan, ketebalan, dan ketahanan terhadap gesekan dan korosi (Noerochiem et al., 2018). Pada proses pelapisan ini dilakukan dengan memberikan 
pencelupan komponen, yang akan diberikan lapisan proteksi kedalam larutan yang mengandung ion-ion logam.

Oleh karena itu material yang akan di lapisi akan diletakan pada katoda yang dihubungkan pada kutub negatif dan anoda, kemudian dicelupkan kedalam larutan yang dihubungkan pada kutub positif (Subayu \& Sakti, 2018).

Kualitas yang baik pada hasil pelapisan dapat dilihat pada kasus struktur permukaan, Permukaan benda yang telah dilapisi yaitu bertujuan untuk mendapat nilai kekerasan dan ketebalan, untuk mendapatkan permukaan yang indah yaitu melakukan salah satu cara dengan diberikannya pelapisan nikelkrom pada benda tertentu (Noerochiem et al., 2018)

Pelapisan logam ini merupakan suatu cara yang dapat mempengaruhi karakteristik yaitu dengan memberikan sifat dari ketebalan pelapisan, kekerasan dan struktur permukaan pada benda kerja, dimana diharapkan benda tersebut mengalami pengaruh dalam hal struktur permukaan maupun ketahanan korosinya. Ketebalan hasil pelapisan di pengaruhi oleh kuat arus maupun lama pencelupan, krom yang yang dilapiskan pada baja karbon akan semakin tebal seiring dengan penambahan variasi kuat arus pencelupan (Pani, 2018).

\section{DASAR TEORI}

\subsection{Electroplating}

Electroplating merupakan suatu proses pengendapan zat ataupun ion-ion logam pada elektroda katoda (negatif) dengan metode elektrolisis (Manurung et al., 2017). Pada kutub positif dikenal dengan anoda dan sebaliknya pada kutub negatif dikenal dengan katoda (Femiana Gapsari, 2017). Prinsip kerja electroplating cocok dengan pernyataan hukum faraday yang berbunyi jumlah zat-zat (unsur-unsur) yang terbentuk serta terbebas pada elektroda selama elektrolisis sebanding dengan jumlah arus listrik yang mengalir dalam larutan elektrolit. Pernyataan faraday tersebut ditulis dengan rumus sebagai berikut ini (Sukarjo \& Pani, 2018).

$$
B=\frac{I t e}{F}
$$

Hubungan antara tegangan serta arus diperlihatkan pada rumus berikut ini.

$$
I=\frac{V}{R}
$$

Berdasarkan rumus tersebut, untuk memvariabelkan arus maka yang divariabelkan hanyalah tahanannya saja sedangkan tegangannya tetap.

\subsubsection{Klasifikasi Electroplating}

Dalam proses electroplating mempunyai fungsi untuk memperbaiki tampak rupa (decorative). Tujuan terdapatnya pelapisan electroplating supaya melindungi logam dari korosi. Tidak hanya itu perubahan sifat mekanik dimana terjadi perubahan kekerasan ataupun perubahan kekuatan tarik dari material yang telah dilakukan pelapisan dengan material yang belum dilakukan pelapisan (Saad \& Aguswendho, 2015).

1. Memperbaiki tampak rupa (decorative), contohnya lapis emas, perak, kuningan, dan perunggu.

2. Melindungi logam dasar dari serangan korosi.

\subsubsection{Prinsip Kerja Electroplating}

Pada prinsipnya, pelapisan logam dengan listrik ialah rangkaian dari arus listrik, elektroda (anoda dan katoda), larutan elektrolit serta benda kerja yang ditempatkan sebagai katoda
(Sudana et al., 2014). Untuk lebih jelasnya rangkaian serta prinsip kerja proses lapis listrik bisa dilihat pada Gambar 2-1.

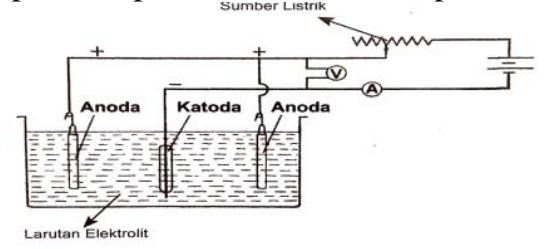

Gambar 0-1 Rangkaian proses pelapisan dengan cara listrik Sumber (A Saleh, 2014)

\subsubsection{Proses Pelapisan Listrik}

Secara garis besarnya proses pelapisan dengan listrik dapat dikelompokkan dalam tiga tahap pengerjaan, yaitu (Kanani, 2004)

1. Proses pengerjaan persiapan/pendahuluan (pre treatment).

a. Menghilangkan semua pengotor yang terdapat di permukaan benda kerja semacam pengotor organik, anorganik/oksida, dan lain-lainnya.

b. Mendapatkan kondisi fisik permukaan yang lebih baik dan lebih aktif.

2. Proses pelapisan dengan cara listrik

Keadaan operasi yang butuh dicermati tersebut antara lain (Novianto, 2018):
a. Rapat arus (current density).
b. Tegangan (Voltage)
c. Temperatur larutan.
d. $\mathrm{pH}$ larutan

\subsection{Baja}

Baja merupakan logam paduan yang terdiri dari logam besi yang memiliki unsur dasar dan karbon, Kandungan yang terdapat di dalam baja yaitu memiliki nilai berkisar mulai dari $0.2 \%-2,1 \%$ berat sesuai tingkatanya. Dapat ditambahkan unsur lain taitu paduan, krom, mangan, nikel, vanadium dan lainya. Karbon pada baja memiliki fungsi sebagai unsur yang meningkatkan kekerasan dan kekuatan tariknya (Afandi et al., 2015)

\subsubsection{Jenis Baja Karbon}

Adapun dapat ditentukan berdasarkan jumlah nilai karbonya yaitu sebagai berikut (Kirono \& Purnomo, n.d.)

1. Baja karbon rendah (low carbon steel) dengan kadar karbon (C) $0,05 \%-0,3 \%$.

2. Baja karbon menengah (medium carbon steel) dengan kadar karbon (C) 0,30\% - 0,50\% (Afandi et al., 2015).

3. Baja karbon tinggi (high carbon steel) dengan kadar karbon (C) $0,6 \%-1,5 \%$ (Manurung, 2017)

\subsection{Karakteristik Baja ST37}

Baja ST37 mempunyai karakteristik seperti baja karbon rendah pada umumnya, baja karbon rendah yang mempunyai kandungan unsur 0,3\% yang akan meningkatkan kekerasan (hardness) sebesar $\pm 170 \mathrm{HB}$ dan kekuatan tariknya, Namun dapat dilihat bahwa disisi lainya membuat menjadi getas dan menurunkan keuletanya. Salah satunya kontruksi mesin yang saling bergesekan sperti roda gigi, jari-jari sepeda motor, rantai dll (Prasetyo et al., 2015) 


\subsection{Pelapisan Nikel}

Pelapisan nickel bertujuan untuk menghindari korosi maupun menambah keindahan secara visual. Senyawa nikel digunakan seperti katalis pada proses electroplating, dengan pelapis nickel (anoda), membutuhkan untuk ditambahkan garam ke bak plating, misalnya nickel karbonat, nickel chloride, nickel fluoborat, nickel sulfamat, serta nickel sulfat. Proses pelapisan nickel dengan listrik terjadi akibat terdapatnya perpindahan ion-ion nickel dari anoda dan larutan sesuai arus listrik yang dialirkan serta mengandap pada permukaan katoda ataupun benda kerja (Anton J. Hartomo \& Tomijiro Kaneko, 1992).

\subsubsection{Jenis Elctroplating Nikel}

Dari tipe dan sistem pelapisan nikel dapat diklasifikasikan menurut larutan elektrolit, sifat-sifat serta penggunaannya (A Saleh, 2014).

Tabel 0-1 Klasifikasi pelapisan nikel

\begin{tabular}{|c|c|}
\hline Larutan pelapis & Sifat-sifat dan Pengunaannya \\
\hline $\begin{array}{l}\text { - Larutan pelapisan mengkilap (bright } \\
\text { plating bath) }\end{array}$ & - Seperti Watt's bath dan atau sulfamat bath \\
\hline - Larutan Watt's (Watt's bath) & $\begin{array}{l}\text { - Pelapisan konvensional (biasa) } \\
\text { - Kecepatan pelapisan tinggi } \\
\text { - Barrel plating } \\
\text { - Larutan standar untuk pelapisan yang bright }\end{array}$ \\
\hline - Nickel suram/dop (Dul/ Nickel TK) & $\begin{array}{l}\text { - Kecepatan pelapisan rendah }\left(0,5 \mathrm{~A} / \mathrm{dm}^{2}\right) \\
\text { - Lapisan tipis } \\
\text { - Barrel plating }\end{array}$ \\
\hline $\begin{array}{l}\text { Larutan asam sulfat-hlorida } \\
\text { (Sulfuric acid chloride bath) }\end{array}$ & $\begin{array}{l}\text { - Butir lapisan lebih baik } \\
\text { - Lapisan lebih ulet } \\
\text { - Mudah dalam pengerjaan buffing }\end{array}$ \\
\hline - Larutan all sulfat (All sulphate bath) & $\begin{array}{l}\text { - pelapisan menggunakan anoda tidak larut } \\
\text { - Sebagai lapisan dasar }\end{array}$ \\
\hline $\begin{array}{l}\text { - Larutan all klorida (All chioride } \\
\text { bath) }\end{array}$ & $\begin{array}{l}\text { - Butir lapisan baik } \\
\text { - Mempunyai kekuatan yang tinggi } \\
\text { - Lapisan lebih halus } \\
\text { - Perpanjangan rendah, tegangan tinggi }\end{array}$ \\
\hline - Larutan strike (striking bath) & - Pelapisan stainiess steel \\
\hline - Larutan nikel hitam (Black nickel) & - Passivating logam \\
\hline - Larutan nikel hitam (Black nickel) & - Pelapisan dekoratif \\
\hline - Larutan sulfamat (Sulfamat bath) & -Kecepatan tinggi \\
\hline
\end{tabular}

Tabel 0-1 Klasifikasi pelapisan nikel (lanjutan)

\begin{tabular}{|l|l|}
\hline \multicolumn{1}{|c|}{ Larutan pelapis } & \multicolumn{1}{c|}{ Sifat-sifat dan Pengunaannya } \\
\hline -Larutan nikel keras & - Kekerasan $425 \mathrm{VHN}$ \\
& - Kuat tarik $1.040 \mathrm{MN} / \mathrm{mm}^{2}$ \\
& - Batas mulur $6 \%$ \\
\hline - Larutan fiuoride & - Pelapisan magnesium \\
\hline - Larutan sulfat tinggi & - Pelapisan langsung pada zinc alloy \\
- Larutan zialit & \\
- Larutan garam kompleks & \\
\hline - Larutan pelapisan mengkilap & - Pelapisan dengan larutan Watt's \\
& - Larutan sulfamat \\
\hline -Larutan komposit & - Disebut dull nickel \\
& - Pelapisan nickel seal \\
& - Dasar lapisan chrom microporous \\
\hline
\end{tabular}

Sumber Electroplating,Ir. Azhar A. Saleh 2014

\subsubsection{Jenis Larutan Elektrolit}

Larutan Eletrolit nikel biasa diberi nama berdasarkan komposisi kimia dan sifat dari larutan. Berdasarkan hal tersebut dan dengan klasifikasi di atas, larutan nikel dapat dikelompokkan (A Saleh, 2014; Anton J. Hartomo \& Tomijiro Kaneko, 1992).

Tabel 0-2 Komposisi dan kondisi operasi larutan nickel strike dan Watt's

\begin{tabular}{|c|c|c|c|c|c|}
\hline \multirow{2}{*}{$\begin{array}{l}\text { Bahan dan Kondisi } \\
\text { Operasi }\end{array}$} & \multicolumn{5}{|c|}{ Konsentrasi Larutan $(\mathrm{g} / \mathrm{L})$} \\
\hline & $\begin{array}{c}\text { Dull } \\
\text { Nickel }\end{array}$ & $\begin{array}{l}\text { Watt's } \\
\text { Bath }\end{array}$ & $\begin{array}{c}\text { All } \\
\text { Sulfat }\end{array}$ & $\begin{array}{l}\text { Sulfat } \\
\text { Chlorida }\end{array}$ & $\begin{array}{c}\text { All } \\
\text { Chlorida }\end{array}$ \\
\hline $\begin{array}{l}\text { Bahan : } \\
\text { - Nikel Sulfat }\left(\mathrm{NiSO}_{4}\right)\end{array}$ & 150 & $220-380$ & 300 & 195 & - \\
\hline - Ammonium Chlorid & & & & & - \\
\hline$\left(\mathrm{NH}_{4} \mathrm{CI}\right)$ & 15 & $30-60$ & & 175 & \\
\hline - Boric Acid $\left(\mathrm{H}_{3} \mathrm{BO}_{3}\right)$ & 15 & $30-45$ & 40 & 40 & 30 \\
\hline Kondisi Operasi : & & & & & \\
\hline $\begin{array}{l}\text {-Temperatur ( } \\
\text {-Rapat arus (A }\end{array}$ & $0,5-6,2$ & $25-10$ & $2,5-11$ & $2,5-12,5$ & $2-12$ \\
\hline $\begin{array}{l}-\mathrm{R} \text { - } \\
-\mathrm{pH}\end{array}$ & $5,8-6,2$ & $2-5,2$ & $3-5$ & 1.5 & 2 \\
\hline -Anoda : Katoda & $2: 1$ & $1: 1$ & & & \\
\hline
\end{tabular}

Sumber Electroplating,Ir. Azhar A. Saleh 2014

Tabel 0-3 Komposisi dan kondisi operasi larutan nikel mengkilap (Bright Nickel)

\begin{tabular}{|c|c|c|}
\hline \multirow{2}{*}{ Bahan dan Kondisi Operasi } & \multicolumn{2}{|c|}{ Konsentrasi Larutan $(\mathrm{g} / \mathrm{L})$} \\
\hline & pHRendah & pH Tinggi \\
\hline Bahan: & & \\
\hline -Nickel Sulfat $\left(\mathrm{NiSO}_{4}\right)$ & 330 & 250 \\
\hline -Nickel Chrorid $\left(\mathrm{NiCI}_{2}\right)$ & 45 & 50 \\
\hline -Boric Acid $\left(\mathrm{H}_{3} \mathrm{BO}_{3}\right)$ & 30 & 40 \\
\hline -Brightener Mnt & $2 \mathrm{ml} / 1$ & $2-3 \mathrm{ml} / \mathrm{l}$ \\
\hline -Brightener MU & $1-2 \mathrm{ml} / \mathrm{l}$ & $1-2 \mathrm{mll}$ \\
\hline Kondisi Operasi : & & \\
\hline -Temperatur $\left({ }^{\circ} \mathrm{C}\right)$ & $40-80$ & $40-80$ \\
\hline -Rapat arus $\left(\mathrm{A} / \mathrm{dm}^{2}\right)$ & $2-3$ & $2-3$ \\
\hline$-\mathrm{pH}^{3}$ & $1,5-4,5$ & $4,5-6$ \\
\hline
\end{tabular}

Sumber Electroplating,Ir. Azhar A. Saleh 2014

Tabel 0-4 Komposisi dan kondisi operasi larutan nikel hitam (Black Nickel)

\begin{tabular}{|c|c|c|}
\hline \multirow[t]{2}{*}{ Bahan dan Kondisi Operasi } & \multicolumn{2}{|c|}{ Konsentrasi Larutan $(\mathrm{g} / \mathrm{L})$} \\
\hline & Ordinary Bath & Chlorida Bath \\
\hline Bahan : & & \\
\hline -Nickel Sulfat $\left(\mathrm{NiSO}_{4}\right)$ & 90 & - \\
\hline -Nickel Chrorid $\left(\mathrm{NiCI}_{2}\right)$ & & 75 \\
\hline -Nickel Ammonium Sulfat & 55 & 30 \\
\hline$\left\{\mathrm{Ni}\left(\mathrm{NH}_{4}\right) \mathrm{SO}_{4}\right\}$ & & \\
\hline - $\mathrm{Zinc}$ Sulfat $\left(\mathrm{ZnSO}_{4}\right)$ & 45 & 30 \\
\hline -Sodium Theocyanate ( $\mathrm{NaCNS}$ ) & 15 & 15 \\
\hline Kondisi Operasi : & & \\
\hline -Temperatur $\left({ }^{\circ} \mathrm{C}\right)$ & T.K & T.K \\
\hline -Rapat arus ( $\left(\mathrm{d} / \mathrm{dm}^{2}\right)$ & $\begin{array}{c}0,5-1 \\
5,8-6,1\end{array}$ & $\begin{array}{c}0,2 \\
5-5,5\end{array}$ \\
\hline
\end{tabular}

Sumber Electroplating,Ir. Azhar A. Saleh 2014

\subsubsection{Proses Pelapisan Nikel}

Sebagai anoda dalam proses lapisan nikel digunakan logam nikel, sebagai katoda benda kerja dan jenis larutan elektrolit jenis watt's bath yang memiliki komposisi $\mathrm{NiSO}_{4}: 220$-380 gr/l, NiCl $2: 30-60 \mathrm{gr} / 1, H_{3} B O_{3}: 30-45$ $\mathrm{gr} / \mathrm{l}$ dan elektrolit $\mathrm{pH}: 5,8-6,2$. Brightener $\mathrm{I}: 2 \mathrm{ml} / \mathrm{l}$, Brightener $\mathrm{M}: 1-2 \mathrm{~m} / \mathrm{l}$ dengan $\mathrm{pH}: 5-5,5$ dan besar rapat arus 0,2 A/dm2 [16]. Kondisi operasi pelapisan memengaruhi dialirkan serta mengandap pada permukaan katoda ataupun benda kerja (A Saleh, 2014).

Tabel 0-5 Klasifikasi pelapisan nikel 


\begin{tabular}{|c|c|}
\hline Larutan pelapis & Sifat-sifat dan Pengunaannya \\
\hline $\begin{array}{l}\text { - Larutan pelapisan mengkilap (bright } \\
\text { plating bath) }\end{array}$ & - Seperti Watt's bath dan atau sulfamat bath \\
\hline - Larutan Watt's (Watt's bath) & $\begin{array}{l}\text { - Pelapisan konvensional (biasa) } \\
\text { - Kecepatan pelapisan tinggi } \\
\text { - Barrel plating } \\
\text { - Larutan standar untuk pelapisan yang bright }\end{array}$ \\
\hline - Nickel suram/dop (Dull Nickel TK) & $\begin{array}{l}\text { - Kecepatan pelapisan rendah }\left(0,5 \mathrm{~A} \mathrm{dm}^{2}\right) \\
\text { - Lapisan tipis } \\
\text { - Barrel plating }\end{array}$ \\
\hline $\begin{array}{l}\text { - Larutan asam sulfat-klorida } \\
\text { (Sulfuric acid chloride bath) }\end{array}$ & $\begin{array}{l}\text { - Butir lapisan lebih baik } \\
\text { - Lapisan lebih ulet } \\
\text { - Mudah dalam pengeriaan buffing }\end{array}$ \\
\hline - Larutan all sulfat (All sulphate bath) & $\begin{array}{l}\text { - pelapisan menggunakan anoda tidak larut } \\
\text { - Sebagai lapisan dasar }\end{array}$ \\
\hline $\begin{array}{l}\text { - Larutan all klorida (All chioride } \\
\text { bath) }\end{array}$ & $\begin{array}{l}\text { - Butir lapisan baik } \\
\text { - Mempunyai kekuatan yang tinggi } \\
\text { - Lapisan lebih halus } \\
\text { - Perpanjangan rendah, tegangan tinggi }\end{array}$ \\
\hline - Larutan strike (striking bath) & - Pelapisan stainless steel \\
\hline - Larutan nikel hitam (Black nickel) & - Passivating logam \\
\hline - Larutan nikel hitam (Black nickel) & - Pelapisan dekoratif \\
\hline - Larutan sulfamat (Sulfamat bath) & - Kecepatan tinggi \\
\hline
\end{tabular}

Tabel 0-1 Klasifikasi pelapisan nikel (lanjutan)

\begin{tabular}{|l|l|}
\hline \multicolumn{1}{|c|}{ Larutan pelapis } & \multicolumn{1}{c|}{ Sifat-sifat dan Pengunaannya } \\
\hline - Larutan nikel keras & $\begin{array}{l}\text { - Kekerasan } 425 \mathrm{VHN} \\
\text { - Kuat tarik } 1.040 \mathrm{MN} / \mathrm{mm}^{2} \\
\text { - Batas mulur } 6 \%\end{array}$ \\
\hline - Larutan fluoride & -Pelapisan magnesium \\
\hline $\begin{array}{l}\text { - Larutan sulfat tinggi } \\
\text { - Larutan zialit } \\
\text { - Larutan garam kompleks }\end{array}$ & - Pelapisan langsung pada zinc alloy \\
\hline - Larutan pelapisan menghilap & -Pelapisan dengan larutan Watt's \\
& - Larutan sulfamat \\
\hline - Larutan komposit & $\begin{array}{l}\text { - Disebut aull nickel } \\
\text { - Pelapisan nickel seal } \\
\text { - Dasar lapisan chrom microporous }\end{array}$ \\
\hline
\end{tabular}

Sumber Electroplating,Ir. Azhar A. Saleh 2014

\subsection{Pelapisan Krom (Chromium)}

Krom (chromium) adalah logam non ferro, mempunyai sifat yang sangat menonjol dan dapat dimanfaatkan yaitu mudah teroksidasi membentuk lapisan krom oksida yang bersifat kaku, tahan korosi, tidak larut dalam asam sulfat dan tidak larut dalam asam nitrat. Dari sifat-sifat tersebut maka krom banyak digunakan sebagai bahan paduan logam besi dalam usaha untuk peningkatan ketahanan korosi, kekuatan serta sebagai bahan pelapis (Sukarjo \& Pani, 2018).

\subsubsection{Pelapisan Krom Dekoratif}

Proses pelapisan krom dekoratif pada dasarnya menitik beratkan pada segi tampak rupa yang menarik dan indah (Sukarjo \& Pani, 2018). Ketebalan lapisan krom dekoratif berkisar antara 0,254-0,5 mikron lebih tipis dibandingkan dengan lapisan nikel yaitu 5\% dari lapisan nikel total (Setyahandana \& Christianto, 2017).

\subsubsection{Pelapisan Krom Keras}

Pelapisan krom keras untuk mendapatkan hasil material yang tahan panas, tahan gores, dan tahan korosi. Pelapisan krom keras dilakukan dengan langsung melapisi benda dengan krom tanpa ada pelapisan perantara. Lapisan pada krom keras lebih tebal dari pada krom dekoratif dengan ketebalan berkisar 0,1-0,3 mm. Manfaat yang didapat dari krom keras diantara logam tersebut(Setyahandana \& Christianto, 2017):
1. Lebih tahan terhadap karat.

2. Dihasilkan lapisan yang lebih keras menjadikan tahan terhadap gesekan.

3. Permukaan logam juga lebih licin.

4. Material terlindungi terhadap karat, gesekan, suhu, dan goresan.

\subsubsection{Jenis Larutan Elektrolit Krom}

Krom tidak dapat diendapkan hanya dari larutan yang mengandung chromic acid $\left(\mathrm{CrO}_{3}\right)$ tetapi harus ditambah satu atau dua macam asam radikal sebagai katalis. . Sampai saat ini jenis dan komposisi larutan krom untuk pelapisan krom dekoratif (Azhar A. Saleh, 2014; Anton J. Hartomo \& Tomijiro Kaneko, 1992).

Tabel 0-6 Komposisi dan kondisi operasi larutan krom

\begin{tabular}{|c|c|c|c|c|}
\hline \multirow[b]{2}{*}{$\begin{array}{l}\text { Bahan dan Kondisi } \\
\text { Operasioanal }\end{array}$} & \multicolumn{4}{|c|}{ Konsentrasi Larutan $(\mathrm{g} / \mathrm{L})$} \\
\hline & $\begin{array}{l}\text { Chromic } \\
\text { Sulfat }\end{array}$ & $\begin{array}{c}\text { Chromic } \\
\text { Fluosilicate }\end{array}$ & $\begin{array}{l}\text { Chromic } \\
\text { Fluorida }\end{array}$ & $\begin{array}{l}\text { Chromic } \\
\text { Alecra }\end{array}$ \\
\hline Bahan: & & & & \\
\hline - Chromic Acid $\left(\mathrm{CrO}_{3}\right)$ & $250-400$ & 250 & $150-200$ & $135-225$ \\
\hline - Asam Sulfat $\left(\mathrm{H}_{2} \mathrm{SO}_{4}\right)$ & $2,5-4$ & $0,8-1$ & $0,8-1,2$ & $0,45-0,75$ \\
\hline - Sodium Fluosilicate & - & $2-3$ & $0,6-0.8$ & - \\
\hline $\begin{array}{l}\text { - Potassium Fluorida } \\
\text { (KBF) }\end{array}$ & - & - & & \\
\hline - Alecra $51 \mathrm{D} / 52 \mathrm{H}$ & - & - & - & $13,5-22,5$ \\
\hline Kondisi Operasi & & & & \\
\hline - Temperatur $\left({ }^{\circ} \mathrm{C}\right)$ & $50-55$ & $45-50$ & $50-55$ & $45-50$ \\
\hline - Rapat arus $\left(\mathrm{A} / \mathrm{dm}^{2}\right)$ & $15-40$ & $16-20$ & $12-18$ & $15-30$ \\
\hline - Derajat Baume ( $\left.{ }^{\circ} \mathrm{Be}\right)$ & $18-22$ & $20-22$ & $18-20$ & $15-21$ \\
\hline - Voltage (volt) & - & - & $4,5-6$ & $6-10$ \\
\hline
\end{tabular}

Sumber Electroplating,Ir. Azhar A. Saleh 2014

\subsubsection{Kondisi Operasi Pelapisan Krom}

Telah dijelaskan di atas bahwa untuk mendapatkan lapisan krom yang mengkilap, kondisi operasi sangat penting untuk diperhatikan sebab setiap larutan mempunyai karakteristik masing-masing sesuai dengan konsentrasi chromic acid dan katalis yang dikandungnya. Hubungan antara rapat arus dan temperatur larutan terhadap hasil lapisan dari tiap-tiap larutan (Azhar A. Saleh, 2014; Anton J. Hartomo \& Tomijiro Kaneko, 1992).

\subsection{Reaksi Kimia Electroplating}

Reaksi kimia merupakan bagian dari cara kerja electroplating yaitu berpindahnya ion logam dengan bantuan arus listrik melalui larutan elektrolit sehingga ion logam tertinggal pada benda padat yang akan di lapisi. Pengendapan bekerja apabila benda kerja yang berlaku sebagai katoda (Nasution \& Sakti, 2018).

Reaksi kimia pembentukan lapisan nikel akan bekerja pada saat melakukan electroplating seperti yang berlaku (Rasyad \& Arto, 2018).

pada katoda :

1. Reaksi pembentukan lapisan nikel.

$$
\mathrm{Ni}^{2+}+2 \mathrm{e} \longrightarrow \mathrm{Ni}
$$

2. Pembentukan gas hidrogen

$$
2 \mathrm{H}^{+}+2 \mathrm{e}^{-} \mathrm{H} \longrightarrow \mathrm{H}_{2}
$$

3. Reaksi reduksi oksigen terlarut

$$
1 / 2 \mathrm{O}_{2}+2 \mathrm{H}^{-} \longrightarrow \mathrm{H}_{2} \mathrm{O}
$$

Pada anoda : 


\section{Reaksi pembentukan gas oksigen}

$$
\mathrm{H}_{2} \mathrm{O} \longrightarrow 4 \mathrm{H}^{+}+\mathrm{O}_{2}+4 e^{-}
$$

2. Reaksi oksidasi gas hidrogen

$$
\mathrm{H}_{2} \longrightarrow 2 \mathrm{H}^{+}+2 \mathrm{e}
$$

Reaksi kimia yag terjadi pada pelapisan krom.

Pada katoda :

1. Reaksi pembentukan lapisan krom

$$
\left(\mathrm{Cr}_{2} \mathrm{O}_{7}\right)^{2-}+14 \mathrm{H}^{+}+6 e^{-} \longrightarrow 2 \mathrm{Cr}+7 \mathrm{H}_{2} \mathrm{O}
$$

\section{Pembentukan gas hidrogen}

$$
2 \mathrm{H}^{+}+2 \mathrm{e}^{-} \mathrm{H} \longrightarrow \mathrm{H}_{2}
$$

3. Reaksi reduksi oksigen terlarut

$$
1 / 2 \mathrm{O}_{2}+2 \mathrm{H}^{-} \longrightarrow \mathrm{H}_{2} \mathrm{O}
$$

Pada anoda :

\section{Reaksi pembentukan gas oksigen}

2. Reaksi gas hidrogen

$$
\mathrm{H}_{2} \longrightarrow 2 \mathrm{H}^{+}+2 \mathrm{e}
$$

\subsection{Uji Pensil Hardness}

Salah satu penelitian pada pengujian kekerasan pensil digunakan pada proses pengecatan car body dan jari-jari sepeda motor yang dilapisi electroplating banyak digunakan didalam produksi pabrik, oleh dikarenakan pengujian pensil hardness yang sederhana, cepat, tidak memerlukan mikroskop. Pengujian pencil kekerasan mitshubishi dilakukan penekanan terhadap benda kerja oleh suatu alat mobil pendorong, pengujian ini dilakukan dengan menerapkan beban dan pensil hardness sesuai ukuran grandenya masing-masing, dengan beban utama yaitu mobil pendorong dengan kemiringan yang sudah ditetapkan. Kemudian beban utama didorong kearah depan sedangkan ujung pensil yang sesuai dengan kekerasanya bertujuan untuk menggoreskan benda uji untuk melihat bekas goresan yang dihasilkan (Murni Cahaya Utama,2021).

\subsection{Uji Ketebalan Lapisan}

Untuk mengetahui pengaruh dari penelitian pelapisan electroplating berpengaruh terhadap perubahan terhadap variasi kuat arus. Dapat diketehui semakin kuat arus meningkat maka ketebalan mengalami peningkatan. Dengan dilakukan pengujian ketebalan melalui mikroskop nikon, yang merupakan suatu alat standarisasi pabrik industri, Untuk mengukur lapisan suatu material, ketebalan produk, dan struktur permukaan dengan mudah dapat diketahui sehingga produk yang di ukur akan selalu terpelihara sesuai standar yang telah ditentukan kualitasnya Pengukur ketebalan merupakan salah satu solusi dalam menjaga kualitas produk industri, terkait dengan ketebalan lapisan dengan menggunakan mikroskop tidak lah sulit hanya dengan cara meletakan dibawah lensa mikroskop, maka permukaan benda uji yang sudah dipotong dapat dilihat hasilnya secara langsung di dalam program digital pada komputer (Yanto, 2018)

\subsection{Struktur Mikro}

Struktur mikro merupakan ketentuan umum yang memiliki susunan yang ditetapkan pada logam dasar dengan logam pelapis. Struktur mikro menunjukkan beberapa perubahan ukuran matriks pada bagian luas area yang dapat mengubah warna pada bagian fasa terang atau gelap, apabila dua logam memiliki struktur kristal dimensi atom yang sama, maka indikasi ini disebut ekpitasi. Penambahan paduan $\mathrm{Cr}$ pada permukaan logam dapat merubah hasil terhadap suatu kekerasan. Sebab perbandingan dimensi atom, atom- atom yang terletak pada susunan awal lapisan epitaksial deposit yang awal terbentuk- terletak dalam kondisi stress, atom- atom terletak dalam kondisi tertekan ataupun tertarik. Sehingga memperoleh wujud butir dan orientasi kristal (Doloksaribu, 2017).

\section{METODELOGI}

\subsection{Alur Penelitian}

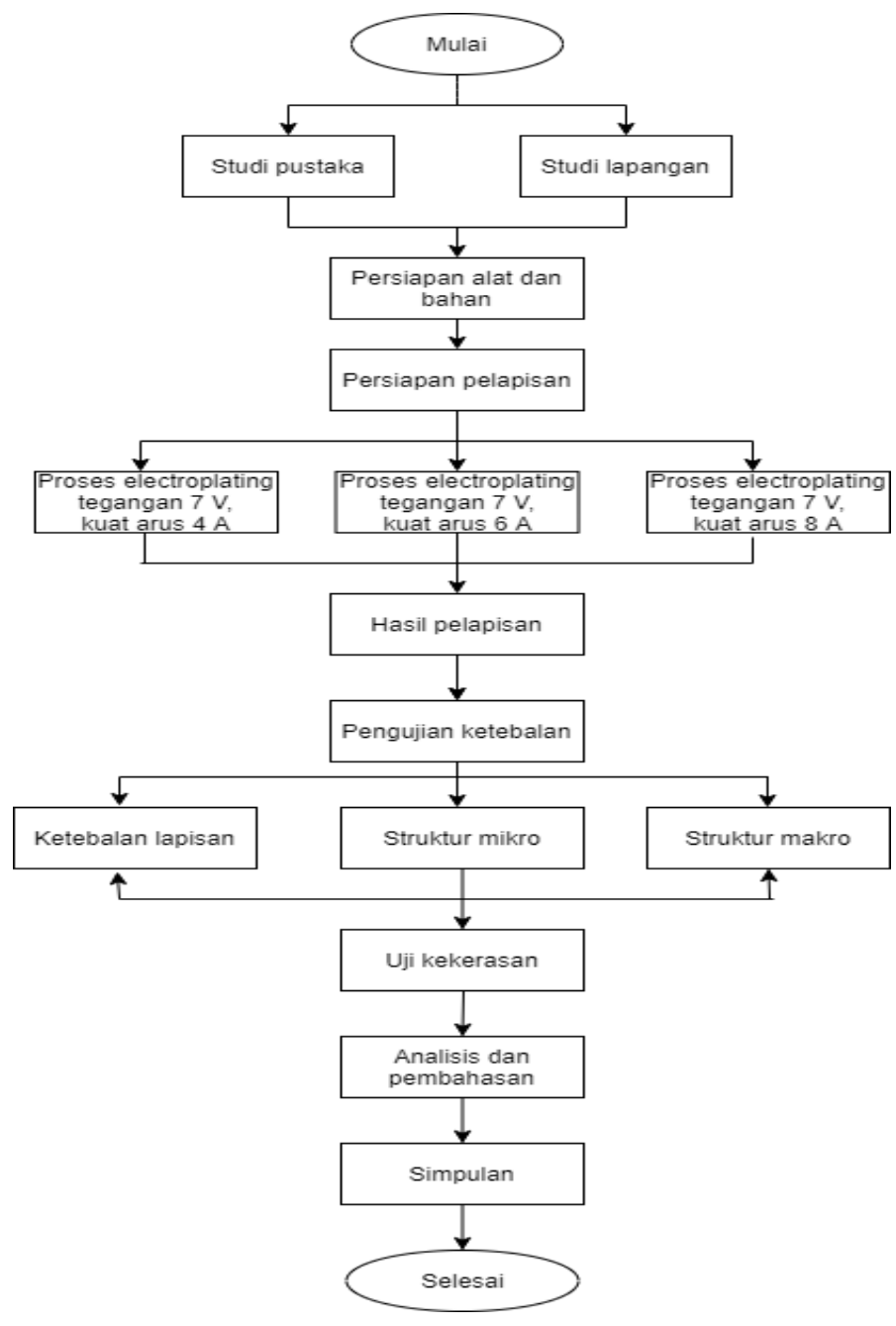

Gambar 0-1 Diagram alir penelitian

\subsubsection{Tahap Awal Penelitian}

Tahap awal penelitian ini adalah tahap dilakukannya untuk mengetahui masalah pada suatu objek dan kondisi tertentu. Pada 
tahap ini juga dilakukan diskusi dengan pembimbing skripsi dan pihak terkait dalam penelitian ini

\subsubsection{Tahap Persiapan Alat dan Bahan}

Pada tahap ini dilakukan pengumpulan alat dan bahan yang bertujuan untuk menghilangkan pada permukaan benda kerja seperti goresan, geram, debu yang menempel, serta menghaluskan permukaan, membersihkan kotoran-kotoran lainnya dengan larutan HCL

\subsubsection{Tahap Pelapisan}

Pada tahap pelapisan krom yang telah di electroplating nikel pada penelitian ini menggunakan variabel bebas yaitu berupa

\begin{tabular}{|l|c|c|c|c|c|c|}
\hline \multirow{2}{*}{ No. } & \multirow{2}{*}{$\begin{array}{c}\text { Kuat } \\
\text { Arus } \\
\text { (Ampere) }\end{array}$} & \multicolumn{5}{|c|}{ Tebal lapisan $(\boldsymbol{\mu m})$} \\
\cline { 3 - 7 } & 4 & $\mathbf{2}$ & $\mathbf{3}$ & $\mathbf{4}$ & $\begin{array}{c}\text { Rata- } \\
\text { rata }\end{array}$ \\
\hline 1 & 4 & 27,52 & 23,61 & 23,27 & 20,07 & 23,61 \\
\hline 2 & 6 & 26,16 & 26,66 & 26,22 & 22,15 & 25,29 \\
\hline 3 & 8 & 26,01 & 26,48 & 27,99 & 26,63 & 26,77 \\
\hline
\end{tabular}

kuat arus 4, 6, dan 8 ampere dengan tegangan 7 volt, proses ini dilakukan dapat mempengaruhi nilai ukuran pada ketebalan dan kekerasan material pada penelitian tersebut.

\subsubsection{Tahap Pengujian}

Pada tahap ini dilakukan beberapa pengujian yaitu ketebalan lapisan dan kekerasan lapisan dengan mikroskop optik metalografi dan pensil kekerasan.

\subsubsection{Pengujian Ketebalan Lapisan}

Pengujian ketebalan lapisan dilakukan dengan mikroskop optik metalografi, yang dilaksanakan dilaboratorium pengujian, Cara operasi prosedurnya yaitu:
1. Proses pemotongan
2. Proses grinding
3. Proses polishing
4. Kalibrasi

\subsubsection{Pengujian Struktur Mikro dan Makro}

Proses pengujian struktur mikro dan makro ini digunakan dengan mikroskop optik metalografi, untuk mengetahui perubahan ketebalan lapisan krom terhadap struktur permukaan baja ST37 yang dilakukan electroplating, pengujian ini dilakukan dengan penyiapan cairan nital berkisar $2 \%$ untuk melakukan suatu proses etsa pada logam untuk menentukan hasil penelitian tersebut.

\subsubsection{Pengujian Kekerasan Krom}

Pengujian kekerasan pada hasil pelapisan nikel-krom dapat diukur dengan cara diletakannya benda kerja pada permukaan datar dibawah mobil pendorong yang akan digoreskan dengan menggunakan pensil hardness dengan kemiringan sudut tertentu untuk mengukur plat baja ST37 dari jari-jari sepeda motor dari hasil electroplating.

\subsubsection{Pengolah Data dan Analisis}

Langkah bagian dari proses pengolahan data yang telah didapat dari hasil penelitian. Tahapan ini merupakan bagian dari pengolahan data yang dituangkan dalam tabel berisi data pengujian kekerasan dan ketebalan hasil electroplating.

\subsection{Metode Penelitian}

Penelitian ini dilakukan dengan menggunakan suatu metode penelitian eksperimental, yaitu dengan melakukan pengamatan akibat dalam suatu proses ekperimen sehingga dapat mengetahui pengaruh variasi kuat arus yang dihasilkan pada pelapisan nikelkrom jari-jari sepeda motor terhadap ketebalan dan kekerasan hasil electroplating pada bahan baja ST37.

\section{HASIL DAN PEMBAHASAN 4.1 Hasil Penelitian}

Berdasarkan data yang telah diperoleh melalui proses pelapisan krom dengan kuat arus 4, 6, dan 8 Ampere, maka di dapatkan data seperti yang di uraikan pada tabel 4-1 dan tabel 4-2 dibawah

\subsubsection{Ketebalan Lapisan Krom \\ Tabel 4 - 1 Nilai Ketebalan lapisan}

\subsubsection{Kekerasan Lapisan Krom}

Tabel 4 - 2 Nilai Kekerasan Lapisan

\begin{tabular}{|c|c|c|}
\hline No. & Kuat Arus & Kekerasan \\
\hline 1. & 4 Ampere & $3 \mathrm{H}$ \\
\hline 2. & 6 Ampere & $4 \mathrm{H}$ \\
\hline 3. & 8 Ampere & $4 \mathrm{H}$ \\
\hline
\end{tabular}

\subsection{Pembahasan}

\subsubsection{Proses Pelapisan Krom}

Penelitian ini telah dilakukan dengan proses electroplating, dengan melalui beberapa tahap pengerjaan mulai dari pembersihkan benda kerja agar bebas dari kotoran, dilakukan pelapisan dengan cara listrik hingga pengerjaan akhir berupa pencelupan yang menghasilkan lapisan nikel dan krom.

\subsubsection{Ketebalan Lapisan Krom}

Berdasarkan data pada Tabel 4.1 dapat dibuat grafik pada Gambar 4-1 dibawah. . Lapisan krom yang terbentuk dari masing-masing kuat arus pada permukaan jari-jari roda sepeda motor, menunjukkan bahwa nilai rata-rata kuat kuat arus $4 \mathrm{~A}$ nilai ketebalan lapisan 23,61 $\mu \mathrm{m}, 6$ A nilai ketebalan lapisan 25,29 $\mu \mathrm{m}$ dan 8 A nilai ketebalan lapisan 26,77 $\mu \mathrm{m}$. Dari grafik tersebut dapat diketahui bahwa dengan semakin meningkatnya kuat arus maka ketebalan lapisan yang terbentuk menjadi semakin tebal. 


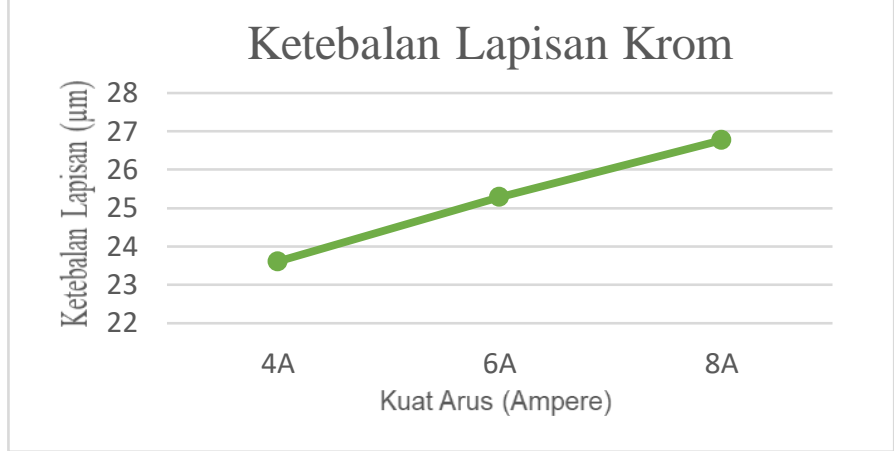

Gambar 4 - 1 Ketebalan Lapisan Krom

Dilihat dengan pengamatan metalografi dengan pembesaran $10 \mathrm{X}$, dapat diketahui ketebalan lapisan nikel-krom Pada Gambar 4-2 menunjukan tebal lapisan krom dengan hasil mulai dari antara 20,07 $\mu \mathrm{m}$ sampai 27,52 $\mu \mathrm{m}$. Pada Gambar 4-3 memperlihatkan tebal lapisan nikel-krom yang menghasilkan nilai ketebalan lapisan antara $22,15 \mu \mathrm{m}$ sampai $26,16 \mu \mathrm{m}$, dan untuk Gambar 4-4 menunjukkan nilai ketebalan lapisan nikelkrom antara $22,15 \mu \mathrm{m}$ sampai $26,16 \mu \mathrm{m}$. Hal ini terjadi karena adanya perpindahan elektron dengan bantuan listrik, maka dapat diketahui bahwa bertambahnya pada kuat arus, maka ketebalan lapisanpun meningkat.

\subsubsection{Kekerasan Lapisan Krom}

Dari pengujian kekerasan pada baja ST37 yang digunakan pada jari-jari sepeda motor dengan memvariasikan kuat arus maka didapatkan data pada Tabel 4-2. Dilakukan pengujian dengan ditempatkan pensil test pada mobil pendorong, kemudian dorong kearah depan dengan mobil pendorong yang diberikan beban konstan $1000 \mathrm{~g}$ minimal 5 goresan dengan kekerasan yang sama, secara bertahap dimulai dari nilai pensil kekerasan terendah 9B dan tertinggi $9 \mathrm{H}$. Jika dari 5 goresan tidak meninggalkan bekas, maka ulangi pensil yang lebih tinggi nilai kekerasanya. Berdasarkan grafik yang di tunjukan pada Gambar 4-5 menunjukkan bahwa semakin bertambahnya kuat arus maka mendapatkan hasil nilai kekerasan mengalami peningkatan di kuat arus 6 ampere,sedangan kuat arus 8 ampere nilainya tetap. Nilai kekerasan lapisan nikel-krom yang terendah adalah pada kuat arus 4 Ampere yaitu sebesar $3 \mathrm{H}$, sementara pada kuat arus 6 Ampere serta 8 Ampere nilai kekerannya masingmasing sebesar $4 \mathrm{H}$. Hasil ini memadahi karena tidak terlalu lunak dan tidak terlalu keras, sehingga dapat mencegah keretakan pada hasil pelapisan krom.

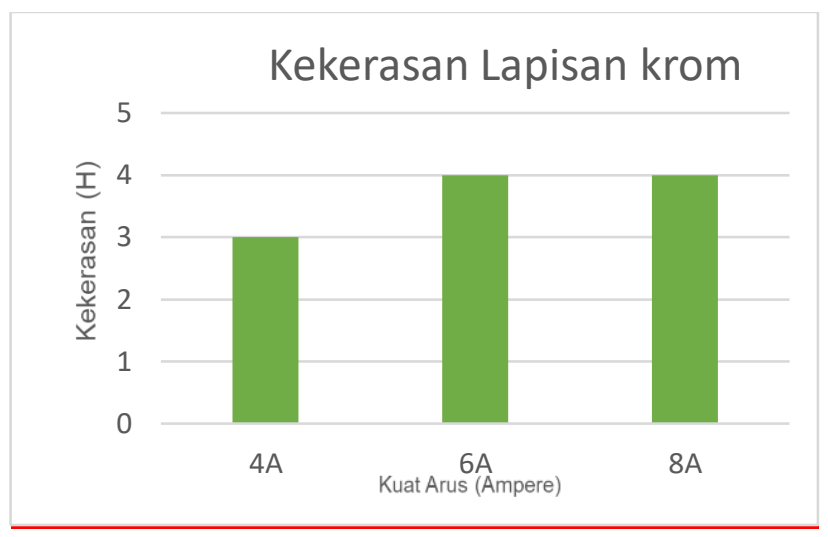

Gambar 4 - 2 Kekerasan Lapisan Krom

\subsubsection{Struktur Mikro Hasil Lapisan Krom}

Berdasarkan pengamatan struktur mikro dengan perbesaran 500 kali, seperti didapatkan pada Gambar 4-6 bahwa menunjukkan struktur mikro yang terjadi antara lapisan $\mathrm{Ni}-\mathrm{Cr}$ pada kuat arus 4 ampere. Lapisan nikel ini ditandai dengan warna gelap dan pada bagian warna terang didominasi lapisan krom dengan susunan lapisan $\mathrm{Cr}$ yang rapat dan merata, pada Gambar 4-7 menunjukkan foto struktur mikro lapisan nikel krom dengan kuat arus 6 ampere yaitu peningkatan endapan $\mathrm{Cr}$ sehingga adanya gumpalan-gumpalan endapan yang tidak merata. pada warna abu-abu ditunjuk sebagai lapisan nikel dan endapan warna hijau kekuningan ditunjuk sebagai lapisan krom, pada Gambar 4-8 menunjukan struktur mikro lapisan dengan kuat arus 8 Ampere. Menunjukkan warna gelap merupakan bagian dari lapisan nikel dan pada bagian warna kuning terang terlihat lapisan krom yang merupakan bagian unsur dari lapisan krom yang bersifat tahan korosi dan non magnetik. Hal ini terjadi karena bahwa semakin meningkatnya kuat arus maka endapan $\mathrm{Cr}$ pun meningkat sehingga membentuk gumpalan pada lapisan ini.

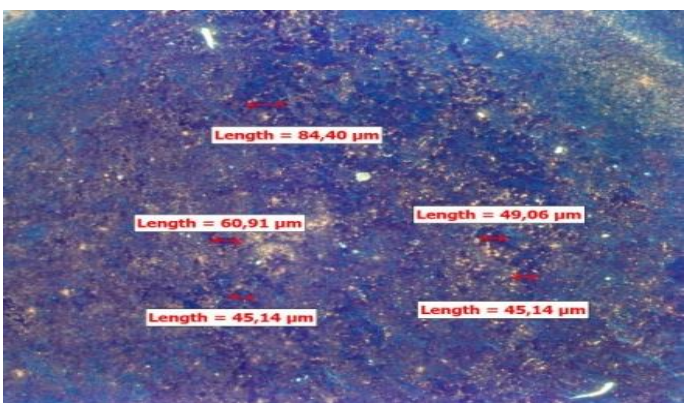

Gambar 4 - 3 struktur mikro pelapisan krom dengan kuat arus 4 ampere

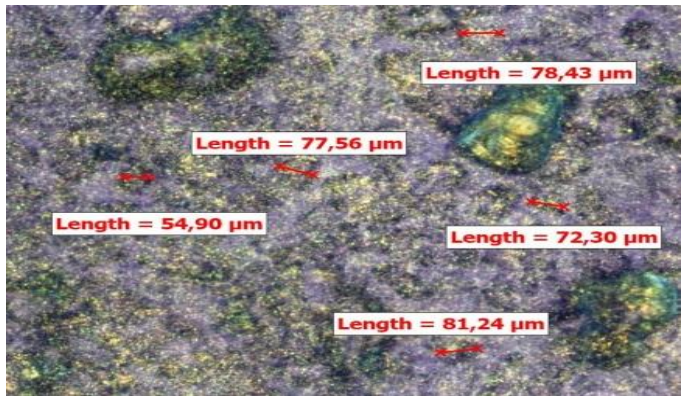

Gambar 4 - 4 struktur mikro pelapisan krom dengan kuat arus 6 ampere 


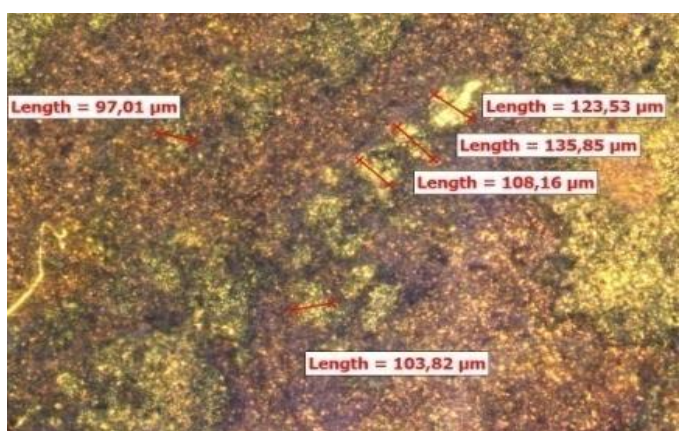

Gambar 4 - 5 struktur mikro pelapisan krom dengan kuat arus 8 ampere

\section{SIMPULAN DAN SARAN}

\subsection{Simpulan}

Berdasarkan hasil pengujian dan pembahasan, dapat disimpulkan bahwa:

1. Ketebalan lapisan krom rata-rata dengan kuat arus $4 \mathrm{~A}$, 6A, dan 8A, masing-masing sebesar 23,61 $\mu \mathrm{m}, 25,29$ $\mu \mathrm{m}$ dan 26,77 $\mu \mathrm{m}$. Hasil ini menunjukkan adanya peningkatan ketebalan lapisan dengan kuat arus yang semakin bertambah.

2. Nilai kekerasan pada daerah pelat baja ST37 dengan kuat arus $4 \mathrm{~A}$ adalah $3 \mathrm{H}$ dan untuk $6 \mathrm{~A}$ dan $8 \mathrm{~A}$ memiliki kekerasan yang sama yaitu $4 \mathrm{H}$

3. Berdasarkan Struktur mikro dengan 500x pembesaran didapatkan peningkatan ketebalan endapan $\mathrm{Cr}$ pada setiap variasi kuat arus yang digunakan.

\subsection{Saran}

Untuk menyempurnakan penelitian ini, dapat disarankan hal-hal sebagai berikut:

1. Perlu adanya penambahan variasi tegangan dan waktu, untuk mengetahui pengaruhnya terhadap ketebalan dan kekerasan lapisan nikel-krom

2. Perlu adanya pengujian daya lekat dan laju korosi, untuk mengetahui kerekatan dan pengaruh lingkungan terhadap bahan.

\section{DAFTAR REFERENSI}

A Saleh, A. (2014). Electroplating Teknik Pelapisan Logam dengan Cara Listrik. Yrama Widya.

Afandi, Y. K., Arief, I. S., \& Amiadji. (2015). Analisa Laju Korosi pada Pelat Baja Karbon dengan Variasi Ketebalan Coating. Jurnal Teknik Its, 4(1), 1-5.

Anton J. Hartomo \& Tomijiro Kaneko. (1992). Mengenal Pelapisan Logam (Elektroplating).

Apriambudi, A. dwi. (2019). Pengaruh Variasi Waktu dan Konsetrasi Larutan terhadap Kekerasan Lapisan Nikel
Electroplating Pada Baja Karbon Rendah. Skripsi.

Doloksaribu, M. (2017). Pengaruh Krom terhadap Sifat Mekanik dan Struktur Mikro pada Besi Cor Nodular 400. Metal Indonesia, 38(1), 8. https://doi.org/10.32423/jmi.2016.v38.8-13

Femiana Gapsari. (2017). Pengantar Korosi (Tim ub press (ed.)). Tim Ub Press.

HD, A. N. S., \& Suheli. (2015). Sifat Fisis dan Mekanik Lapisan Nikel- Chromium pada Permukaan Baja Aisi 410. 48-54.

Kanani, N. (2004). Metal Finishing - A Key Technology? Electroplating, 1-19. https://doi.org/10.1016/b978185617451-0/50001-4

Kirono, S., \& Purnomo, A. (n.d.). Analisa Karakteristik Material Spoke Wheel dengan Cast Wheel pada Pelek Sepeda Motor. 27-36.

Manurung, C. (2017). Pengaruh Kuat Arus terhadap Ketebalan Lapisan dan Laju Korosi (mpy) Hasil Elektroplating Baja Karbon Rendah dengan Pelapis Nikel.

Manurung, C., Pasar, M. J., Puri, K., \& Sari, T. (2017). Pengaruh Kuat Arus terhadap Ketebalan Lapisan dan Laju Korosi (mpy) Hasil Elektroplating Baja Karbon Rendah dengan Pelapis Nikel. 45.

Meol, P. K., Maliwemu, E. U. K., Mesin, J. T., \& Cendana, U. N. (2016). Pengaruh Tegangan Listrik Dan Waktu pada Krom Plating terhadap Keausan pada Hasil Produk Pengecoran Aluminium Scrap. 03(01), 47-54.

Nasution, D. I., \& Sakti, A. M. (2018). Pengaruh Jarak Anoda Katoda dan Waktu Pencelupan pada Proses Pelapisan Nikel-Krom terhadap Ketebalan dan Kekerasan Lapisan Permukaan Knalpot Sepeda Motor. Jtm, 06(01), 41-49.

Noerochiem, L., Nurdiansah, H., \& R, M. A. (2018). Pengaruh Variasi Waktu Pencelupan terhadap Ketebalan, Kekerasan dan Ketahanan Korosi Hasil Elektroplating Nikel-Hard Krom pada Baja AISI 4340. 7(2), 2301-9271.

Novianto, E. (2018). Studi Pelapisan Krom pada Baja Karbon dengan Arus 5 Ampere dan Variasi Tegangan 3, 6, 7.5, 9, 12 volt dengan Waktu Pencelupan 50 menit.

Pani, S. (2018). Pengaruh Variasi Kuat Arus Listrik dan Waktu Electroplating terhadap Ketebalan Lapisan Permukaan. Prinsip Dasar Electroplating Ahmad, 2011 . Prinsip dasar dari proses lapis listrik berpedoman atau berdasarka. 2(1), 18-25.

Prasetyo, S. D., Septe, E., \& Mahyoeddin, J. (2015). Studi Korosi Temperatur Tinggi Baja ASSAB 760 di lingkungan Klor dan Sulfur. Jurnal Teknik Mesin.

Rasyad, A., \& Arto, B. (2018). Analisis Pengaruh Temperatur, Waktu, dan Kuat Arus Proses Elektroplating terhadap Kekuatan Tarik, KRasyad, A., \& Arto, B. (2018). Analisis Pengaruh Temperatur, Waktu, dan Kuat Arus Proses Elektroplating terhadap Kekuatan Tarik, Kekuatan Tekuk dan Kekerasa. Jurnal Rekayasa Mesin,

Saad, A., \& Aguswendho. (2015). Karakteristik Pelapisan Krom terhadap Produk Logam sebagai upaya meningkatkan mutu di Sumatera Barat. Jurnal Teknik Mesin, 5(2), 8387.

Setyahandana, B., \& Christianto, Y. E. (2017). Pengaruh Hard Chrome Plating pada Peningkatan Kekerasan Baja Komponen Kincir. Jurnal Teknologi, 12(1), 26-35.

Subayu, R. D., \& Sakti, A. M. (2018). Pengaruh Variasi Kuat Arus dan Tegangan Pada Proses Elektroplating Nikel Terhadap Ketebalan Permukaan dan Mampu Bending Knalpot Sepeda Motor. Jtm, 6(1), 121-128. 
Sudana, I. M., Ida Ayu Anom Arsani, \& Waisnawa, I. G. . S. (2014). Alat Simulasi Pelapisan Logam dengan Metode Elektroplating Simulation Tool With Metal Coating. Logic, 14(3), 190-198.

Sukarjo, H., \& Pani, S. (2018). Pengaruh Variasi Kuat Arus Listrik dan Waktu Electroplating Nickel-Chrome terhadap Ketebalan Lapisan pada Permukaan Baja Karbon Rendah. Jurnal Engine, 2(1), 18-25.

Surya Darmawan, A. D., Dewa Ketut Okariawan, I., \& Herlina Sari, N. (2015). Pengaruh Variasi Kuat Arus Listrik dan
Waktu Proses Electroplating terhadap Kekuatan Tarik, Kekerasan dan Ketebalan 2 Lapisan pada Baja Karbon Rendah dengan Krom, The Influence Variation of Strong Electric Current Time and Process Electroplating Power of Att. Dinamika Teknik Mesin, 5(2), 66-71.

Yanto, D. D. (2018). Pengaruh Elektroplating Nikel terhadap Ketebalan Lapisan, Kekasaran, dan Kekerasan Permukaan Titanium dengan Variasi Waktu 20, 40, 60, 80 Menit. International Reviews of Immunology, 1-15. https://doi.org/10.3109/08830185.2014.902452 